International Journal of Library and Information Science Studies

Vol.8, No.1, pp.1-8, 2022

Print ISSN: 2059-9056 (Print)

Online ISSN: 2059-9064(Online)

\title{
THE ROLE OF LIBRARIES IN PROMOTING ENTREPRENEURSHIP EDUCATION IN NIGERIAN UNIVERSITIES
}

\author{
Ogar, Christopher Eje, Ph.D. (CLN) \\ Principal Librarian, Federal University Otuoke, Bayelsa State \\ Affiong Bassey Moses, Ph.D. (CLN) \\ University Library, Cross River University of Technology Calabar
}

\begin{abstract}
With rapid development in technology and entrepreneurship, every university is expected among other things to train persons to become specialists imbued with the spirit of creativity and ability for practical work, become good citizens and promote the culture of national unity and progress. Students and staff in this respect, need to have information on the trends of their progression. Information is vital to the overall academic development of university students. It is central to the development of a nation or a people. Therefore, this paper accesses the Role of Libraries in Promoting Entrepreneurship Education in Nigerian Universities. It also concludes that, information has always played a central role in human life and it is central and paramount for effective and fast development of a nation. Indeed, modern economics are driven by entrepreneurship. Without entrepreneurship ability to organize a country natural endowment, such as a country can hardly achieve her effective potential output/productivity. The paper recommends among other things. This paper recommended among other things that university library management and their universities should give priority attention to entrepreneurship education. Adequate resources and services should be provided to promote teaching, learning and research. Integration of this course into the school curriculum is necessary.
\end{abstract}

KEYWORDS: libraries, promotion, entrepreneurship education, Nigerian universities.

\section{INTRODUCTION}

A library generally serves as the heart of any educational institution without which the institution can be said to be dead in terms of knowledge generation and dissemination. Thus, a library is established to provide information service to enable the institution achieve excellence in the performance of its functions of research, teaching and community services. Students and staff, in this respect, need to have information on development of their profession. With rapid development in technology and entrepreneurship as a topic and contentious issues, every university is expected among other things to train persons to become specialists imbued with the spirit of creativity, acquire preliminary ability of practical work, become good citizens and promote the culture of national unity and progress (Federal Republic of Nigeria, 2004). 
Information is vital to the overall academic development of university students. Use of information depends on its availability and the format the user is acquainted with. Using relevant information improves quality service provision to students and also help them to improve on their skills and acquire new knowledge. "Students must be equipped with the information skills that allows them to remain viable in the face of enormous uncertainty and constant change" (Webster, 2002).

In popular usage, the term "information" refers to facts and opinion provided and received during the course of daily life. Oyegade (2000) defined information and knowledge communicated or received in relation to a particular subject. Muhammed (1994) reiterates that information is "vital resource which provides impetus for a nation`s social, cultural, spiritual, political, economic, scientific and technological advancement; greater socio-political equality; and effective and efficient governance, power and fellowship". However, scholars in information studies have made attempt to define the term. Alhassan \& Saka (2008) citing Buckland (1991) as reported by Capurro and Hjorland (2004) analyzed various uses of the term information in information science when he stated that it can be used in relation to things, process and knowledge. Saracevic (1999) considered the term information in three senses: as signal and messages (narrow senses); that are cognitively processed (broader sense). Information can thus be taken to be data that have being processed and analyzed for retrieval in whatever format it may be.

The new webster`s Dictionary of English Language (1992) define information as knowledge obtained by search, study, etc, and Grundnitski (1989) views it technically as "data that have been put into meaningful and useful context and communicated to a recipient who uses it to make decisions". Daniel (1986) sees it as "knowledge used in its generic sense irrespective of the sources, format, mode or transfer medium". Thus, the term "information" is processed data. Facts or ideas meant to convey intelligible meaning for use.

The objectives of information are not only to arouse consciousness reawaken interest and participation in any endeavor, but also sharpens one's vision, articulation and focus: restores one's confidence to aspire and enables one to fully understand one's rights, duties and obligation and to assist in solving problems. information is an essential ingredient for every activity. in addition, it keeps people emotionally and psychologically to your environment. According to Opeke (1993). The major function of information is to increase the knowledge of the user; to reduce his level of uncertainty, arouse interest and participation or to reduce the variety of choices available to him. If everyone possesses the perfect knowledge of his (one's) information needs as basic to decision making, then perfect knowledge is guaranteed.

It is this view that makes Idoka (2003) to assert that:

Nothing then is important for mankind than to bring within reach all What can widen his horizon, making discoveries a literacy transformation that can make the individual a more valued members of the Society.

Information on entrepreneurship helps individual to become an entrepreneur or to enlarge his job prospects. Availability of information justifies the need for Nigerian students to develop skills they 
require to develop an entrepreneurial orientation and mindset as a necessary preparation for the business, vocational and professional lives after their former university education. Well, the concept of entrepreneurship is not entirely a new one. It has always been there, especially when we know that entrepreneurship has to do with creativity, innovation, drive foresight, imagination, initiative, persistence and what have you. Indeed, modern economics are driven by entrepreneurs. It has rightly been asserted that despite a country's abundant endowments: adequately labour supply, technological knowledge and capital, without entrepreneurial ability to organize them, such a country can hardly achieve have potential output/productivity.

The concept of entrepreneurship is a term used to describe the underlining spirit or force towards the establishment of a new business venture or significant improvement of an existing business organization or improving the managerial techniques for effective achievement of organizational objectives. It is the process by wish individuals either on your own or inside organization pursue opportunity without regard to the resources they currently control (Stevenson \& Jarillo (1990). It connotes an inner urge, creativity and imagination, in doing something new with a view to making profit. this is the reason for their assertion that entrepreneurs are innovators and risk takers. Entrepreneurship is a process of creating something new with value by devoting necessary time and effort, assuming and accompanying financial psychic, and social risks and receiving the resulting rewards of monetary ${ }^{\mathrm{n}}$ and personal satisfaction and Independence (Hisrich, Peters and Shepherd, 2008). According to Anyanwu and Nwosu (2008) entrepreneurship covers virtually every idea that meets these criteria:

-it is something you know how to do and can do well;

-It is something you like to do and will not mind be doing it day after day;

-It is something with broad appeal to sell on a steady basis;

-It can be sold at a price that will cover all expenses and overhead plus return on a healthy profit; -Interest is very important for entrepreneurship to thrive.

\section{Major Roles and Aspects of Entrepreneurship are:}

-Entrepreneurship involves creating something new and/or of value to both the entrepreneur and the audience (customers) for which the product or service was developed;

-entrepreneurship requires devotion, necessary time and effort. Entrepreneurship requires a lot of time and effort to make something new and make it operational;

-The third party involves the reward of being an entrepreneur. The reward includes independence, personal satisfaction and huge profit (money reward) from the Risk taken;

-The final aspect of entrepreneurship is uncertainty about action taken. This is the reason why the entrepreneur takes calculated risks through preparation of business plan, feasibility study, which is a roadmap or a guide that facilitate achievement of their set objectives.

Entrepreneurship could also be self-employed after graduation. it is the starting and operating your own business at a viable alternative to been employed in an established company or government parastatals after graduation. Research continue to support the notion that entrepreneurship plays a key role in creating innovation, wealth and employment (Ismail at al, 2011; Jones, Beynon and 
Vol.8, No.1, pp.1-8, 2022

Print ISSN: 2059-9056 (Print)

Online ISSN: 2059-9064(Online)

Packham, 2009). Studies also indicate that entrepreneurship can be encouraged through education and training.

Furthermore, entrepreneurship is one of the four factors of production. Other factors, land, labour and capital cannot function effectively without the entrepreneur who transforms and blends them to achieve the desired objectives of an organization. Specifically, Ekanem and Umanah (2010) stated five objectives of entrepreneurship education as follows:

- $\quad$ promoting entrepreneurship attitude and skills among learners;

- $\quad$ Promoting development of personal qualities that are relevant to entrepreneurship such as creativity, spirit of initiatives, risk-taking and responsibility;

- $\quad$ Offering early knowledge of a contact with the world of business and some understanding of the roles of entrepreneurs in the community;

- $\quad$ Raising students' awareness of self-employment as a career option (the message been that you can become not only an employee but also an entrepreneur);

- $\quad$ Organizing activities based on learning by doing, for example, by means of students running on how to start a business especially in vocational or technical schools and at the university level (EGEE, 2004).

By completing their academic education with entrepreneurship, they are leveraged with qualities and skills they need to become more relevant in today's global market places. The importance of this research therefore lies on the effort to relate the role of libraries in promoting entrepreneurship education in Nigerian universities.

\section{The Role of libraries in promotion of entrepreneurship education in Nigerian University}

The role of libraries in promotion of entrepreneurship education in Nigerian universities can be felt in the following areas:

\section{Information Literacy:}

Information literacy is a prerequisite for university undergraduate to successfully survive and compete in the 21 st century and beyond. One of the ways of stimulating the active use of the resources and services is by teaching the library users how to search for and retrieve materials in the library to support learning and research. (Eden and Lawal, 1996). One of the strategies for effective information services delivery can be done through information literacy. The concept may have several definitions but the one mostly cited in literature was provided by the American Library Association Presidential Committee on Information Literacy report in 1989 as:

To be information literate an individual most recognize what information is needed and have the ability to locate, evaluate and use effectively the information needed.

Information literacy posits and individual who can recognize what information is needed, has the ability to locate, evaluate and effectively use the needed information. Adelazeez as sited in Omar (2009) posits that information literacy is concerned with the teaching and learning about whole 
range of information sources and format. The concept of information literacy has been interpreted in various ways since the early seventies.

In entrepreneurship education information literacy could be referred to as the acquisition of skills, knowledge and competencies and develop the ability to identify, locate, evaluate and effectively use information needed by student's entrepreneurship education. Like any other field, students in entrepreneurship departments and teachers involved in entrepreneurship education must be information literate especially at this era of ICT age. This is because for librarians and students as well as teachers to be relevant at this computer age, they must be computer literate. This will enable them to be actively engaged in learning, teaching research and other services as listed below, hence, entrepreneurship education must be rich in theories and practice. User education to entrepreneurship on the use of libraries with special reference to education, need be given a priority attention.

\section{Instant Messaging:}

The service is a trend aimed at replacing the notice board and making reference services more effective in the library. This service is a very useful feedback tool presenting some interesting opportunity for the library to reach out to users, especially in relation to reference service. Questions are answered immediately and in real time via Short Message System (SMS) or Instant Messaging (IM). Access to this information should be available to all including entrepreneurship education students.

\section{Collection Development}

Quality Management of libraries depend largely on how the libraries have been able to utilize available human and material resources. The value of collection is measured by their usability as well as quality and size. The ALA (2006) stipulate that libraries should provide varied authoritative and up-to-date resources that support its mission and needs of undergraduates. It states that since there is no absolute standard for the size of a collection supporting undergraduate needs, the essential thing is to see that the resources adequately support their needs. Also, according to the believe of Ventura College Accreditation Team (2001) an initial to total minimum collection of 50,960 volumes of books, serials, video and film and other items to a maximum of 378,000 for 19,000 faculty students in an excellent collection and a maximum of 32,870 to 198,400 volumes of books, serials, videos etc as maximum collection (Adebayo, 2006). Other recommendations on basic collection inside those made by Ifidon (1985) and Clap and Jordan (1985), they recommend that 50,000 and an annual increase of 15,000 volumes for an enrolment of 600 students is ideal.

The recommendation should include library collections or resources on entrepreneurship education. Collection development and curriculum of the school should provide adequate and indepth resources both in human and material resources upon which entrepreneurship students would be bound to all entrepreneurial students and other stakeholders in entrepreneurship education businesses. 
Vol.8, No.1, pp.1-8, 2022

Print ISSN: 2059-9056 (Print)

Online ISSN: 2059-9064(Online)

\section{E-Resources Management Services:}

The librarians must procure and subscribe to e-books and journals on entrepreneurship in their libraries. After procuring and subscribing these e-books and journal resources, the librarian must alert or notice their users of the university community via Short Message Service (SMS), E-mails and social network tools to create awareness of the availability of such e-resources. This has also helped the library management to plan properly about the subscription and optimum use of the eresources.

\section{Provision of Research Tools:}

The acquisition and provision of writing and research tools by the librarian is another action which helped users to easily gather, manage, store and share all types of information as well as generate citations and bibliographies. These tools which are: Ref Works, Textract and Endnotes have further help users to customize and refine writing and researching to suit their unique needs.

\section{Provisions of Current Materials:}

The quality and quantity of library materials and services provided makes up a library and not only the building. There must be provision of the primary, secondary and tertiary sources of entrepreneurship information to have a functional library such as books, journals, reports and other related materials. Current awareness services such as bibliographies, reading lists, indexes and abstract, displays, exhibition contribute a lot in informing the clientele of the library holdings. These services should be made available to students and academic staff of the Department of entrepreneurship education.

\section{Effective Cataloguing:}

An unorganized library is a bookstore and not a library. There must be a systematic way of arranging these library materials for easy retrieval of information on entrepreneurship. Therefore, for cataloguing to be effective to the clientele a recognized classification schemes should be used in organizing knowledge in the university library.

\section{Web Presence:}

This create publicity to the new information and information resources. Web services delivery of information through the web pages is a current development that enhances current awareness service delivery to students in the department of entrepreneurship education.

\section{CONCLUSION}

Information is being increasingly recognize as a critical resource development at all levels of government. Information is an essential ingredient for every activity including entrepreneurship education. One can readily infer that information has always played a central role in human life; it is central to development of people and a nation and paramount for an effective and fast development. Indeed, modern economics driven by entrepreneurs. Without entrepreneurial ability to recognize it countries abundant natural and endowments, such a country can hardly achieve her potential output/productivity. Thus, information has become a prime commodity of the present age 
Vol.8, No.1, pp.1-8, 2022

Print ISSN: 2059-9056 (Print)

Online ISSN: 2059-9064(Online)

and its role is really appreciated in every sphere of human and nation's existence. Provision of information help people especially undergraduates in tertiary institutions at the end of their programme to be self-employed, create jobs for others and play active role in the economic development of Nigeria. It is recommended that:

- Since information is central to any entrepreneurship, when made available to entrepreneurs, it should the meaningful and useful, to give it value for the end users. The goal of information must be right and complete information to the right person at the right time in the correct format and at the least possible time. it must therefore be relevant and should also be provided about the progress made toward specified gains or interests/or lost. Information packaging must be attractive and easy to understand (clarity) and use.

- Librarians in Nigeria universities must become proficient in the use of the new technologies to promote them and instruct students and teachers in their use. As students become more selfdirected learners, the librarian as a resource person in the students quest for supporting information and development of appropriate presentation strategies. Using relevant information improves qualities service provision to students and allow them to remain viable in the face of enormous uncertainty and concerns change.

\section{References}

Adebayo, E. L. (2006). Quality assurance on the implications for the management of University Library in Nigeria. A paper presented at the National workshop organize by the committee of University Library of Nigerian Universities (CULNU) held at the NUC Auditorium, Abuja, 3rd-4th May, 1-13.

ALA (2006). Quote in Adebayo, E. L. (2006). Quality assurance and the implication for the management of university libraries in Nigeria. A paper presented at the national workshop organized by the committee of University Librarians of Niheria University (CULNU) held at the NUC Auditorium, Abuja 3rd-4th May, 3

Alhassan, J. A. \& Salad, A. K. (2008). Information need some steam behavior of Engineering lecturers in federal university of Technology Minna, H-JOLIS: Heartland journal of library and information science, 2(1\&2), 42-51.

Anyanwu, F. A. \& Nwosu, B. O. (2008). The practice of entrepreneurship. Owners: Ecosatat.

Clap, V. W. and Jordan, R. T. (1986). Qualitative criteria for adequacy of academic library collections. College and research libraries.

Daniel, C. (1989). Information needs of civil servants in Kaduna State. Unpublished BLS project. Zaria, ABU: 112.

Eden, N and Lawal, O.O. (1996). Towards improved user education programme in Nigeria University Libraries, African journal of libraries, archives and information science, 6(1). 31-40

EGEE (2004). Final report of the expert group "education for entrepreneurship" making progress in promoting entrepreneur attitude and skills through primary education. Brussels, February (2004) P.12. 
Vol.8, No.1, pp.1-8, 2022

Print ISSN: 2059-9056 (Print)

Online ISSN: 2059-9064(Online)

Ekanem, E. and Umanah, P. C. (2010). Innovative entrepreneurship management: implications and challenges to Nigerian managers. Journal of Educational innovators. 8(2), 46-54

Federal Republic of Nigeria (2004). National policy on education: Lagos: NERD Press

Grundnitski (1989). The integrity of digital information. American journal of information science. 20(1), 210

Hisrich, R. D. Peters, M. P. \& Shepherd, D. A. (2008). Entrepreneurship. 7th Ed. New York: McGraw-Hill

Idoka, H. J. (2003). A study of Ryan society: its organization and changes. Chicago: Houghton Publication. P. 36

Ifidon, S. E. (1985). Essentials of management of African university libraries. Lagos: Libri services 22

Jones, P. Beynon, M. J. \& Packham, G. (2009). Investigation the motivation for understanding enterprise education. A Carb based exposition. Retrieved 12th April, 2012 from: http://www.label.Org.UK/Content/Assets/BP09-Pauljones.pdf

Muhammed, Z. (1994). Towards bringing the information gap in developing countries: the case of Nigeria. International information and library review. Academic press, 26, 91

Opeke, R. (1993). The role of information in the management of local government. Paper presented at the workshop on information management for councilors and local government administrators at the university of Ibadan, March/April, 11

Oyedage, E. A. (2000). An overview of information technology in Nigerian public libraries. A paper presented at the 10th Biennial conference of the national association of library and information science educators (NALISE). P.60

Stevenson, H. H. and Jarillo, J. C. (1990). A paradigm of entrepreneurship strategy. Management journal (special edition), 11, 17-27

Umar, B. D. (2009). Library and librarian in information literacy for lifelong learning in university education. The information manager, 9(2), 23-29

Webster, Frank (2000). International capitalism. Theories of the information society. 2nd edition. New York: Routledge 